\title{
First Report of Citrus Aleurocanthus woglumi Ashby (Hemiptera: Aleyrodidae) in the State of Paraná, Brazil
}

\author{
Rúbia de Oliveira Molina ${ }^{1 *}$, William Mário de Carvalho Nunes ${ }^{2}$, Luciano Grillo Gil ${ }^{1}$, \\ Dirlene Aparecida Moreno da Fonseca Rinaldi ${ }^{3}$, José Croce Filho ${ }^{3}$ and Regina Célia Zonta \\ de Carvalho ${ }^{3}$ \\ ${ }^{1}$ Instituto Agronômico do Paraná; Londrina - PR - Brasil. ${ }^{2}$ Universidade Estadual de Maringá; Maringá - PR - \\ Brasil. ${ }^{3}$ Agência de Defesa Agropecuária do Paraná; Maringá - PR - Brasil
}

\begin{abstract}
The citrus blackfly Aleroucanthus woglumi Ashby, (Hemiptera Aleyrodidae) is an important pest that occurs in citrus groves, native to south-east Asia. In Brazil, according to the Ministry of Agriculture, this is a quarantine pest (A2) under official control IN 52, 2007 (MAPA) and is not widespread in the country. The insect can infest more than 300 host plants, including cultivated plants, ornamentals and weeds, but mostly occurs in the plants of the genus citrus. This paper is the first report of citrus blackfly in the State of Paraná.
\end{abstract}

Key words: Citrus, Citrus pest, Aleyrodid

\section{INTRODUCTION}

The blackfly Aleroucanthus woglumi is an important pest that occurs in the citrus crops, native to south-east Asia (Dietz and Zetek 1920), and is widespread throughout the Americas, Africa, Asia and Oceania (Oliveira et al. 2001; Eppo 2012). The blackfly is an insect from the order Hemiptera, suborder Sternorrhyncha, comprising an important agricultural family Aleyrodidae, subfamily Aleyrodinae, genus Aleurocanthus (Nguyen and Hamon 2003; Gallo et al. 2002). In Brazil, its only one species is known A. woglumi Ashby. Taxonomic studies have shown Aleurocanthus punjabensis Corbertt and $A$. husaini known as synonymously to $A$. woglumi Ashby (Eppo $\mathrm{n}^{\circ}$ 103) species. It is commonly known as "mosca-negra dos citros", "mosca prieta de los citrilos", "citrus blackfly" or "aleurode noir des agrumes". It's the first occurrence was reported in 1913 in Jamaica, spreading to Cuba in 1916 and Mexico in 1935 (Smith et al. 1964). In the United States, its dissemination covers central and southern Florida, from Cross Creek to Key West (Nguyen and Hamon 2003). In South America, it is present in Colombia, Venezuela, Ecuador, Peru, Guiana, Suriname and Brazil (Cunha 2003).

In Brazil, the blackfly is a quarantine pest (A2). It is not widespread and is under official control IN 52, 2007 (MAPA 2013). It was first reported in the state of Pará in 2001 (Oliveira et al. 2001). Later on it was detected in Amazonas in 2004 (Ronchi-Teles et al. 2009); in Maranhão in 2003 and 2004 (Lemos et al. 2006); in Amapá in 2006 (Jordão and Silva 2006). In São Paulo, its occurrence was reported in 2008 (Pena et al. 2008); in 2009 in Paraíba (Lopes et al. 2010) and in Roraima (Correia et al. 2011).

*Author for correspondence: rubiamolina@iapar.br 
The blackfly has more than 300 host plants (Oliveira et al. 1999), which include cultivated plants, ornamentals and weeds, but it mostly occurs in the plants of the genus Citrus, Cashew (Anacardium occidentale L) and avocado (Persea americana Mill (Drees and Jackman 1998). Pena et al. (2009), based on laboratory studies in Brazil proved that the most favorable host plant of $A$. woglumi is the Tahiti lime (Citrus latifolia) when compared to sweet orange (Citrus sinensis) and mango (Mangifera indica). However, according to the recent Normative Instruction $\mathrm{n}^{\mathrm{o}} 23$, from April $29^{\text {th }}$ of 2008, the following plants are subjected to the insect infestation: Poplar (Populus spp.), White Mulberry (Morus spp.), Ardisia (Ardisia swartz Swartz.), Banana Tree (Musa spp.), Common Box (Buxussem pervirens Sabamiki), Arabica Coffee (Coffea arabica L.), Starfruit (Averrhoa carambola L.), Cherimoya (Annona cherimola Mill.), Night-Blooming Cestrum (Cestrum nocturnum Linn.), Ginger (Zingiber officinale Roscoe), Guava (Psidium guajava L.), Soursop (Annona muricata L.), Grumichama (Eugenia brasiliensis Lam.), Chinese Hibiscus (Hibiscus rosasinensis L.), Plumeria (Plumeria rubra L.), Lychee (Litchi chinensis Sonn.), Laurus (Laurus nobilis L.), Papaya (Carica papaya L.), Mango (Mangifera indica L.), Passion Fruit (Passiflora edulis Sims.), Quince (Cydonia oblonga Mill.), Orange Jessamine (Murraya paniculata (L.) Jack.), Pear (Pyrus spp.), Sugarapple (Annonas quamosa L.), Pomegranate (Punica granatum L.), Rose (Rosa spp.), Sapodilla (Manilkara zapota L.) and Common Grape vine (Vitis vinifera L.), (MAPA 2012).

The insect can harm the citrus production due to the way it feeds, sucking out the sap from the Phloem, therefore removing the nutrients and possibly debilitating the plant and injecting toxins (Silva et al. 2011). This insect also eliminates secretions with a high dosage of sugars, which favors the appearance of saprotrophic fungi in the leaves of the plant, an example is the sooty mold (Campinodium citri Berk and Desm) (Oliveira et al. 1999). This fungus is known for growing thick and dark on the leaves and fruits of citric plants, possibly impairing the photosynthesis due to the decrease of solar incidence. Economically speaking, the commercialization of these fruits naturally can be compromised, as there is a depreciation of the fruits contaminated by the fungi due to the alteration in its appearance.

The objective of this work was to report the first occurrence of the blackfly in a commercial citrus orchard in the State of Paraná.

\section{MATERIALS AND METHODS}

The species A. woglumi was identified for the first time in Paraná in a phytosanitary inspection under the inspection Terms 64158 (MAPA) in $05 / 13 / 2011$. The blackfly was collected in leaf samples sweet orange (Citrus sinensis) Pera variety, in an commercial orchard eight year old, located on the Onze Irmãos road in the city of Mandaguaçu, PR; coordinates UTM -23,385389 Latitude and 52,082657 Longitude. The identification was done in the Diagnostic Center "Marcos Enrietti" (CDME), the official laboratory of the department of Inspection and Agricultural Defense of the Paraná State Department of Agriculture and Supply (SEAB).

\section{RESULTS AND DISCUSSION}

The presence of all the developmental phases of A. woglumi was observed: (Fig. 1A) eggs (in a spiral posture), (Fig. 1B) nymphs $\left(1^{\text {st }}, 2^{\text {nd }}\right.$ and $3^{\text {rd }}$ instars), (Figs. 1C and D) adults. The pupae were macerated, clarified and assembled on permanent slides with Canada balsam (approximately 20 slides with 3 to 5 pupae/slide). The assembly process was done according to Martin (1987). The adults and the leaves containing postures and nymph stages were set in $70 \%$ alcohol. The identification occurred through the electronic key identification (Martin 1987).

Due to the importance of citric plantations in the state of Parana and the variety of host plants of this insect, also taking in account the damage caused to the plants due to their feeding system, it is indispensable to pay attention to the control of this insect in the northwest region of Paraná. There is an imperious need for further studies to comprehend the behavior, biology and control methods of this pest. 


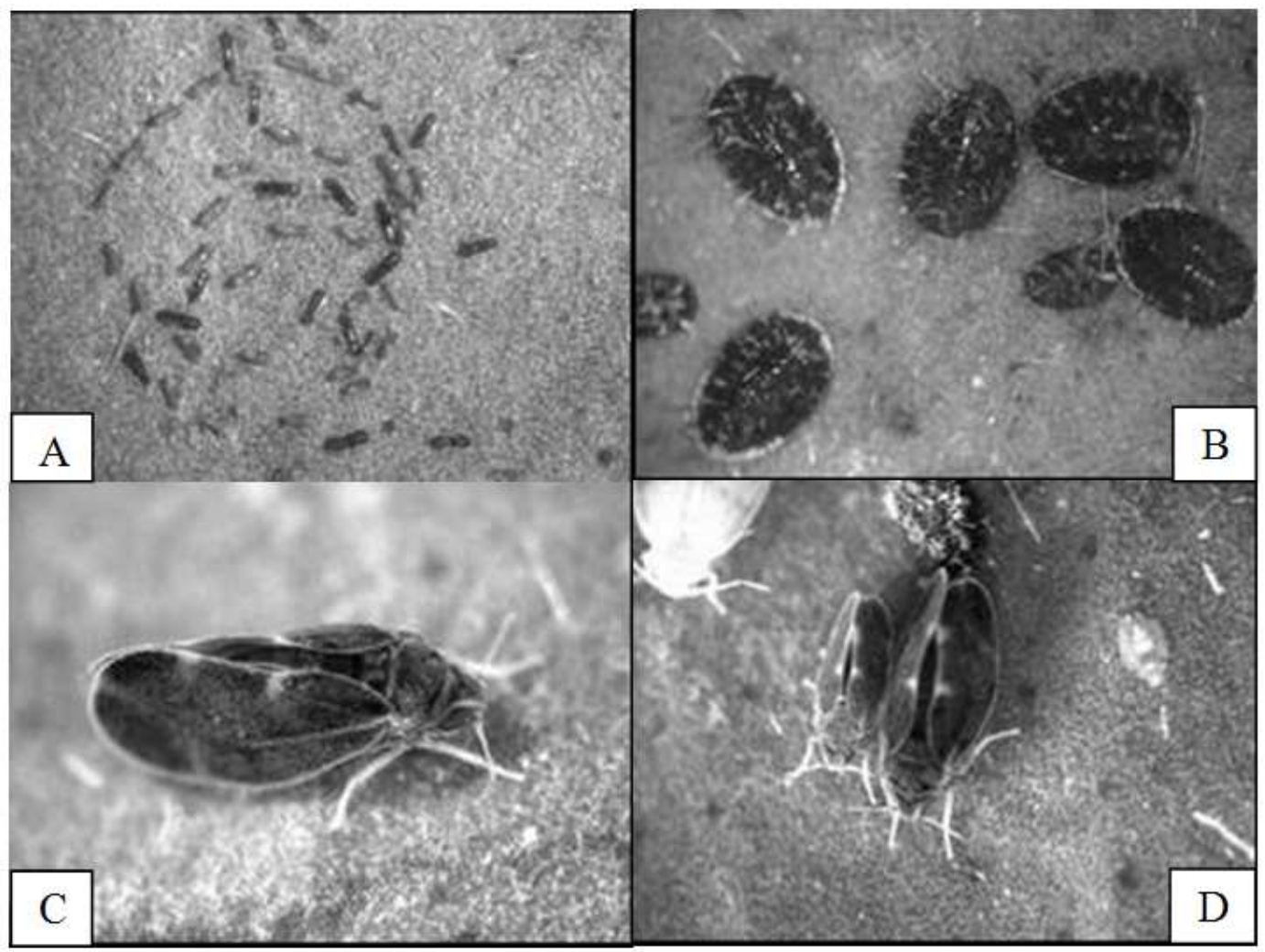

Figure1 - Blackfly in the citrus Aleurocanthus woglumi, A-eggs, B-nymphs, C e D-Adult.

\section{REFERENCES}

Correia RG, Lima ACS, Farias PRS, Maciel FCS, Silva MW, Silva AG. Primeiro registro da ocorrência de mosca-negra-dos-citros, Aleurocanthus woglumi Ashby, 1915 (Hemiptera: Aleyrodidae) em Roraima. Revista Agro@mbiente On-line [internet]. 2011 [cited 2013 Feb. 10]; 5: 245-248. Available from: http://revista.ufrr.br/index.php/agroambiente/article/v iew/487.

Cunha MLA, Distribuição geográfica, aspectos biológicos e controle químico da mosca negra dos citros, Aleurocanthus woglumi Ashby (Hemíptera: Aleyrodidae), nas condições ambientais do Estado do Pará. [Dissertação de mestrado]. Belém: Universidade Federal Rural da Amazônia; 2003.

Dietz HF, Zetek J. The blackfly of citrus and other subtropical plants. USDA Dep Agric. 1920; 885: 1-55.

Drees BM, Jackman JA. A field guide to Texas insects. Houston: Gulf Publishers, 1998.

Gallo D, Nakano O, Silveira Neto S, Carvalho RPL, Baptista GC, Berti Filho E, Parra JRP, Zucchi RA, Alves SB, Vendramim JD, Marchini LC, Lopes JRS, Omoto C. Entomologia Agrícola, Piracicaba: FEALQ; 2002.
Jordão AL, Silva RA. Guia de Pragas Agrícolas para o Manejo Integrado no Estado do Amapá. Ribeirão Preto: Editora Holos; 2006.

Lemos RNS, Silva GS, Araújo JRG, Chagas EF, Moreira AA, Soares ATM. Ocorrência de Aleurocanthus woglumi Ashby (Hemiptera: Aleyrodidae) no Maranhão. Neotrop Entomol. 2006; 35: 558-559.

Lopes EB, Brito CH, Batista JL, Silva AB. Ocorrência da mosca-Negra-dos-citros (Aleurocanthus woglumi) na Paraíba. Rev Tecnol Ciên Agropec. 2010; 4: 19-22.

Ministério da Agricultura, Pecuária e Abastecimento (MAPA). Instrução Normativa MAPA/DAS $\mathrm{n}^{\circ}$ 20/2002 [Internet]. 2012 Dec 10 [cited 2013 Apr 20]. Available from: http://extranet.instruçãonormativa. gov.br DAS No 2329 de abril.

Ministério da Agricultura, Pecuária e Abastecimento (MAPA). Lista de pragas quarentenárias presentes(A2) [internet]. 2011 Abr. 01 [cited 2013 Apr 23]. Available from: http://extranet.agricultura.gov.br.

Ministério da Agricultura, Pecuária e Abastecimento (MAPA). 2007. Ministério da Agricultura, Pecuária e Abastecimento. Instrução Normativa $\mathrm{N}^{\circ} 52$, de 20 de novembro de 2007 [internet]. 2007 [cited 2013 Apr 23]. Available from: http://extranet.agricultura.gov.br /sislegis-consulta. 
Martin JH. An identification guide to common whitefly pest species of the world (Homoptera, Aleyrodidae) Trop. Pest Manag. 1987; 33: 298-322.

Nguyen R, Hamon AB, 2003. Citrus blackfly, Aleurocanthus woglumi Ashby (Homoptera: Aleyrodidae). University of Florida. 2003.

Oliveira MRV, Silva CCA, Návia D. Praga quarentenária A1 a mosca-negra-dos-citros, Aleurocanthus woglumi Ashby (Hemiptera: Aleyrodidae). Brasilia: Ministério da Agricultura, Pecuária e Abastecimento; 1999.

Oliveira MRV, Silva CCA, Návia D. Mosca negra dos citros Aleurocanthus woglumi: Alerta quarentenário. Brasília: Ministério da Agricultura, Pecuária e Abastecimento, 2001.

Pena MR, Vendramim JD, Lourenção AL, Silva NM, Yamamoto PT, Gonçalves MS. Ocorrência da moscanegra-dos-citros, Aleurocanthus woglumi Ashby (Hemiptera:Aleyrodidae) no estado de São Paulo. Rev Agro. 2008; 83: 61-65.
Pena MR, Silva NM, Vendramim JD, Lourenção AL, Haddad ML. Biologia da Mosca-Negra-dos-Citros, Aleurocanthus woglumi Ashby (Hemiptera: Aleyrodidae), em três plantas hospedeiras. Neotrop Entomol. 2009; 35: 558-559.

Ronchi-Teles B, Pena MR, Silva NM. Observações sobre a ocorrência de Mosca-Negra-dos-Citros, Aleurocanthus woglumi Ashby, 1915 (Hemiptera: Sternorrhyncha: Aleyrodidae) no estado do Amazonas. Acta Amaz. 2009; 39: 241-244.

Silva AG, Farias PRS, Boiça Junior AL, Souza BH, S. Mosca-Negra-dos-Citros: Características Gerais, Bioecologia e Métodos de Controle dessa Importante Praga Quarentenária da Citricultura Brasileira. Entomol Brasilis. 2011; 4: 85-91.

Smith HD, Maltby HL, Jimenez, EJ. Biological control of the citrus blackfly in Mexico. USDA-ARS, Technical Bulletin. 1964; 1311: 1-30. 